\title{
Water Governance 2.0: A Review and Second Generation Research Agenda
}

\author{
Eduardo Araral • Yahua Wang
}

Received: 2 January 2013 / Accepted: 12 June 2013 /

Published online: 28 June 2013

(C) The Author(s) 2013. This article is published with open access at Springerlink.com

\begin{abstract}
Water scholars and practitioners generally agree that improving water governance is the key to addressing water insecurity in developing countries. We review the literature on water governance and argue for a second-generation research agenda, which pays more attention to the study of incentive structures, is multi and inter-disciplinary in orientation and with clear policy implications. We then illustrate how theories drawn from public economics, new institutional economics, political economy and public administration can help diagnose the challenges of integrated water resources management, improving efficiency of water utilities, privatization of utilities and public-private partnerships, water pricing reforms, virtual waters/water trading, among others. We conclude that these tools can help advance the second-generation research agenda on water governance.
\end{abstract}

Keywords Water governance · Disciplinary foundation · Public sector economics · Institutional economics $\cdot$ Political economy $\cdot$ Public administration

\section{Introduction}

Water scholars, policy makers and donors over the last decade generally agree that improving water governance holds the key to solving water insecurity in developing countries (Rogers and Hall 2003; Gopalakrishnan et al. 2005; Kashyap 2004; Saleth and Dinar 2005; Hoekstra and Chapagain 2007; Briscoe 2009; Biswas and Tortajada 2010; Global Water Partnership 2000; OECD 2011). The World Water Vision Report, for instance, blamed bad institutions, bad

\footnotetext{
E. Araral

Lee Kuan Yew School of Public Policy, National University of Singapore, 469C Bukit Timah Road, Singapore 259772, Singapore

e-mail: sppaej@nus.edu.sg

Y. Wang $(\bowtie)$

School of Public Policy and Management, Tsinghua University, Beijing 100084, China

e-mail: wangyahua@tsinghua.edu.cn
} 
governance, bad incentives, and bad allocations of resources as the root causes of the problem (Cosgrove and Rijsberman 2000).

The challenges of water governance are most acute in developing countries. As Briscoe (2009) notes, poor countries often suffer from the problem of "bad hydrology", i.e. more frequent floods and droughts, higher levels of uncertainties, rapid growth in water demand, small endowments of water infrastructure, fragile institutions and face more uncertainties arising from climate change. The result, he argues, is more water insecurity and more conflicts within and between countries particularly in poor countries.

We review the literature on water governance in the last decade and argue for a secondgeneration research agenda - water governance 2.0 - which pays more attention to the study of incentive structures, is multi and inter-disciplinary in orientation and with clear policy implications. We then illustrate how theories drawn from public economics, new institutional economics, political economy and public administration can help diagnose incentive issues associated with water governance such as integrated water resources management, improving efficiency of water utilities, privatization of utilities and public-private partnerships, water pricing reforms, virtual waters/water trading, among others.

Specifically, we illustrate how theories drawn from 1) public sector economics; 2) institutional economics; 3) political economy and 4) public administration can provide the tools to advance the research agenda for water governance 2.0. Figure 1 provides a schematic illustration of these four sets of complementary diagnostic tools which we elaborate in Section 3 of the paper.

In brief, public economics is concerned with the welfare (i.e. efficiency and equity) implications of water policy. Its theoretical core - market failures - is based on the theory of the commons, property rights, externalities, natural monopolies and public goods. These theories provide an economic rationale for the government to play a significant role in water resources management and water supply but problems associated with government failures pose their own set of challenges.

The institutional economics approach on the other hand is concerned with the efficacy and cost effectiveness of institutional alternatives to water governance (i.e. private, public, hybrids). Its theoretical core derives from the interrelated theories of transaction, contract and property rights. For instance, contract and transaction cost theories can help provide a robust explanation for the general failure of water utilities privatization in the last 20 years and the challenges of public-private-partnerships for water service. Transaction cost theory likewise can help explain the challenges of integrated water resources management.

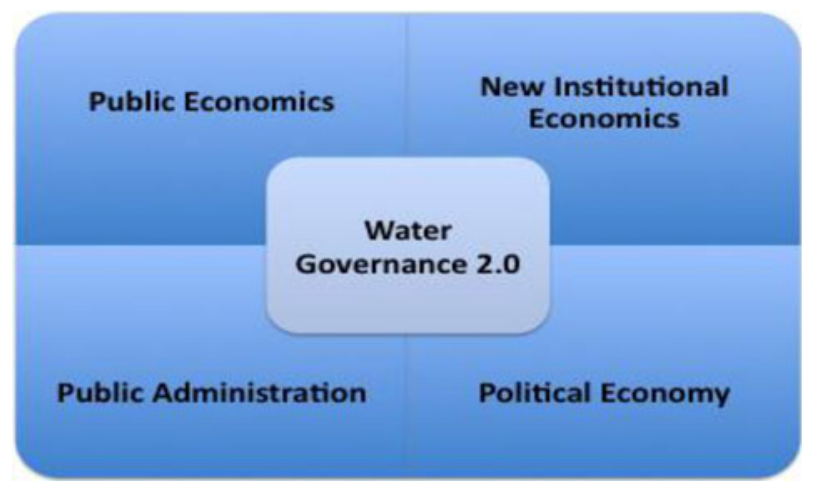

Fig. 1 Disciplinary foundations for water governance 2.0 
The political economy approach on the other hand is concerned with, as the term suggests, the interaction between the politics and economics of water. Its analytic core draws on noncooperative game theory as well as theories of collective action and public choice. Political economy theories have been used to explain the challenges of water governance (see for instance, Shirley 2002).

Finally, the public administration approach is concerned with explaining variations in the performance of water bureaucracies using theories of government failures as well as agency theory as their theoretical cores. Theories of government failure have been used to explain the rather poor performance of public water utilities and irrigation agencies in many developing countries, for instance Araral $(2008,2009)$.

The paper is structured as follows. The next part briefly reviews the extant literature on water governance. We then describe the four analytic tools, their theoretical foundations, empirical examples and most importantly their implications for water policy. Finally, we conclude with the implications for theory, methods, empirics and practice of water governance.

\section{Literature Review}

\subsection{Water Governance Literature}

The Global Water Partnership (2002) defined water governance as "the range of political, social, economic and administrative systems that are in place to develop and manage water resources, and the delivery of water services, at different levels of society."

This definition, however, is problematic because practically the entire literature on water policy, economics, finance, politics, regulation, law and management would fall under this definition. At the minimum, this definition lacks a coherent analytic framework and diagnostic value as it is mainly descriptive. It also suffers from a specification problem because the mechanisms to develop and manage water resources are often not well specified and thus their operational implications for research and water policy are unclear.

The UNDP Water Governance Facility (2013) on the other hand provides a more nuanced and concrete definition. It argues that water governance should address, among other things, "principles such as equity and efficiency in water resource and services allocation and distribution, water administration based on catchments, the need for integrated water management approaches and the need to balance water use between socio-economic activities and ecosystems." It also calls for the "clarification of the roles of government, civil society and the private sector and their responsibilities regarding ownership, management and administration of water resources and services."

This definition, however, while more nuanced than the first and provides guiding principles and clear policy implications, falls short in terms of diagnostic and prescriptive utility. We argue that for research on water governance to be useful, it should diagnose and tackle incentive problems beyond statements of general principles.

Biswas and Tortajada (2010) argue that the term water governance has replaced the terms 'sustainable water management' and 'integrated water resources management' (IWRM) which have been the main water paradigms from the 1980s to 2000. Tropp (2007), on the other hand refers to water governance in terms of the "evolution of formal and informal networks, partnerships, jointdecision making processes including dialogue and negotiated outcomes as mechanisms for steering water governance." Wiek and Larson (2012) summarize some key features of water governance as "a systemic perspective, a governance focus on social actors, a transparent and accessible discourse on values and goals, and a comprehensive perspective on water sustainability." 
Mollinga (2008) employs a political sociology approach and argue that water governance is a politically contested domain. While this approach may have something of value to social theory, it does not tell us much about politics per se particularly the mechanisms that generate water conflicts, the alternatives arrangements to resolve them and their implications for efficiency, equity and sustainability. Thus, the theoretical and practical significance of this research agenda for improving water governance is limited. Similarly, Hirsch (2006) argues that catchment governance, in this case in the Mekong, should be understood as "an arena for negotiating more sustainable, equitable, and productive use and management of water at multiple scales." Others such as Kashyap (2004) referred to water governance as "the ability to develop adaptive capacity" and Godden et al. (2011) as "adaptive and sustainable water management" in the context of climate change. Stein et al. (2011) applies a social network analysis in the study of the structure of the water governance network in Tanzania and conclude that social network analysis "can serve as a tool to 'ground' network building efforts towards the creation of locally anchored institutions."

Other scholars who study global water governance take a more behavioral approach. For instance Pahl-Wostl et al. (2008) define the term as "the development and implementation of norms, principles, rules, incentives, informative tools, and infrastructure to promote a change in the behavior of actors at the global level in the area of water governance." This definition, however, suffers the same fate as the Global Water Partnership and that of the UNDP.

\subsection{Comments on the Literature}

Several observations can be said about the literature. First, there appears to be little consensus on the scope and definition of water governance. We argue that for the concept to be valuable, it has to be analytically coherent, has predictive value, can diagnose the incentive structure of the problem, and has clear implications for policy.

Second, scholars understandably have approached the subject from their own disciplinary orientations - from sociology, political science, institutions, behavioral science, economics, international relations, among others. They have paid attention to issues related to efficiency, equity, integration, sustainability and participation, but seldom examine their tradeoffs.

Third and consequently, water governance research has not evolved into a multi and interdisciplinary agenda. Analytic tools from economics, sociology, politics and public administration are seldom brought together despite the fact that water governance problems have multi and interdisciplinary dimensions.

Fourth, the literature is generally descriptive and argumentative and offers little theoretical coherence. The literature generally does not provide robust analysis of the incentive issues that we argue should be the core of water governance research. As a result, it is often weak in diagnostic and predictive value and consequently offers little implication to water policy.

Finally, there is no consensus yet on how to approach the study of water governance. Some scholars such as Saleth and Dinar (2005) employs a comparative approach, comparing water governance indicators among countries based on 3 sets of indicators (water law, policy and administration) and 20 sub-indicators that are commonly discussed in the literature.

Other scholars such as Biswas and Tortajada (2010) propose an alternative approach based on independent and objective case studies of good practices of water governance. In particular, their proposal is to study the "enabling environment and critical factors that contributed to their success which could allow others to significantly improve their current practices and processes." It is our view that the approaches by Saleth and Dinar (2005) and Biswas and Tortajada (2010) are in fact complementary approaches that can help strengthen research on water governance. 


\section{Water Governance 2.0}

Based on our brief review of the literature on water governance, we argue for a secondgeneration research agenda, one that pays more attention to the study of incentive structures, is multi and inter-disciplinary in orientation and with clear policy implications. In this section, we illustrate how theories drawn from public economics, new institutional economics, political economy and public administration can help diagnose incentive issues associated with water governance. We argue that these analytical tools can help complement the approaches proposed by Saleth and Dinar (2005) and Biswas and Tortajada (2010) to advance the study of water governance.

\subsection{Public Economics}

Public economics is primarily concerned with how public policies affect social welfare. Its core diagnostic tool is the idea of market failures, which occurs when reliance on a free market leads to inefficient social outcomes. In this section, we explore the concept of market failures as it applies to water governance, in particular the concepts of externalities, missing or non-functioning markets, public goods/common pool resources.

Rogers and Hall (2003) catalogued several implications of market failures in the water sector. For instance, upstream-downstream externalities in river basins can lead to environmental, economic, and social externalities, which provide economic justification for government intervention. This problem of externalities has provided the theoretical foundation for integrated river basin management as a mode of governance. In practice, they are important reasons resulting in the concept of integrated river basin management remained problematic that the political and administrative transaction costs in large river basins are high and capacities of governments in developing countries remain weak. Second, nonpriced assets and missing markets, or some aspect of water services such as flood control, are not priced which can lead to their sub-optimal provision and production. Missing water markets has provided the theoretical basis for proposals to facilitate or simulate the functioning of water markets through assignment or auction of water rights. Water markets are already functioning in Southwest United States (Brewer et al. 2008; Brown 2006; Brookshire et al. 2004) and Australia (Brooks and Harris 2008; Harris 2011). However, in some developing countries, prohibitive transaction costs and weak institutional frameworks (i.e. unclear water rights and weak enforcement mechanisms) make water trading in these countries more challenging (Wang et al. 2008).

Third, flood control and water quality protection can often be public goods while most water investments involve economies-of-scale making them natural monopolies. Economies of scale has provided the theoretical foundation for the continuing central role of the government in making investments in the water sector and has implications in the design of risk allocation mechanisms for public-private partnerships in water.

Finally, ignorance and uncertainty about water hydrology makes it difficult for markets to set prices correctly and therefore fail to adequately provide for socially optimal levels of these goods. All of these provide an economic rationale for governments to play a central role in water governance but problems of government failure - which we discuss below-compounds the problem.

We agree with Rogers and Hall (2003) that many, if not most, of water governance issues arise from the characteristics of water resources and water services mentioned above. In addition, we argue that the theoretical and practical implications of these market failures for our understanding of water governance remain underdeveloped. We illustrate this with three 
examples. First, externalities in river basin governance such as cross-boundary and intersector water management, are often cited as a justification for pursuing river basin organizations and integrated water resource management (IWRM).

Biswas (2004), however, has argued that while the concept of IWRM looks attractive, a deeper analysis brings out many problems, both in concept and implementation, especially for meso to macro-scale projects. The definition of IWRM, he argues, continues to be amorphous, and there is no agreement on fundamental issues like what aspects should be integrated, how, by whom, or even if such integration in a wider sense is possible. We agree with this critique and add that debates on the value of IWRM are academic unless it can be compared to the next best institutional alternative. Absent this comparison, it is unproductive to pass judgment on one institutional solution without reference to the next best alternative.

Despite these valid criticisms, IWRM remains a popular and widely used concept in water management around the world in both developed and developing economies (e.g. Chikozho 2008; Timmerman et al. 2008; Ako et al. 2010). In fact, the apparently successful case of managing one of the world's largest river basins - the Yellow River Basin in China with an area of 752,000 square kilometers - is now being offered as an argument that IWRM is possible even for such a scale. In this case, the Yellow River Conservancy Commission, authorized by the central government, implemented water allocation regulations to prevent the cutoff of continuous flow in the lower Yellow River since 1990s (Wang and Ching 2013).

Second, it is commonly argued that water services should be subsidized and kept in the control of government for several reasons: water is essential to life, water supply has natural monopoly characteristics and because it is a critical infrastructure. As a critical infrastructure, water supply requires tight coordination of its core transactions in order to maintain technical integrity as well as economic coherence in the system (Menard 2008).

For these reasons, governments worldwide continue to regulate its price, quality and standards of service. Indeed, at least $85 \%$ of water utilities worldwide are under the control of governments but it is also the case that most of these utilities are often poorly performing. This leads to an important question that has not been adequately resolved: how can the governance of public water utilities be improved to make them more efficient, responsive and sustainable? Many studies (e.g. Rogers and Hall 2003; Weimer and Vining 2005; Araral 2008) suggest that a key solution is to give them autonomous status but the political economy of water makes this more difficult in practice.

Third, water trading has been proposed as a key solution to the problem of water scarcity. However, the prohibitive costs of water trading and unclear water rights has led to governments taking a more active role in facilitating the emergence of quasi water markets - through legal infrastructure and the assignment of water rights which would otherwise fail in a market setting. Examples of these include water markets in Chile (Bauer 2004) and more recently in China (Wang 2012). However, in some developing countries with weak legal infrastructure, where water rights are unclear and enforcement is often weak or corrupted, water markets remain undeveloped and are less likely to succeed (Bjornlund and McKay 2002).

A related concept to direct water trading is the notion of virtual waters. Its central implication is that water-short countries could import water-intensive agricultural products from waterabundant countries, while using their limited domestic water resources for higher valued activities (Yang and Zehnder 2007; Abu-Sharar et al. 2012). This idea is an adaptation of the notion of comparative advantage in international trade. Critiques, however, suggest that while the idea is compelling and provides a helpful perspective, it is a misleading and insufficient policy criterion because it is not based on a theoretical framework and not consistent with the economic concept of comparative advantage (Wilchens 2010).

A similar idea is the notion of water footprints, a body of work associated with Hoekstra and Chapagain (2007). The main idea — an adaptation of the notion of carbon footprints - is 
that while the river basin may be the appropriate unit of analysis for planning and institutional arrangements, this may not always be sufficient to deal with contemporary water issues. This is because many of today's water issues have (sub) continental or even global dimension, which demands a governance approach that comprises coordination and institutional arrangements at a level above that of the river basin.

For Hoekstra (2009), several developments have converged to provide the rationale for the water footprint approach. First, local issues of water scarcity and flooding, he argues will be enhanced or weakened by human-induced global climate change. Second, local problems of water pollution are often intrinsic to the structure of the global economy. Third, there is a growing presence of multinationals in the drinking water sector. Fourth, several national governments are developing plans for large-scale inter-basin water transfers. Fifth, an increasing number of water-short countries seek to preserve their domestic water resources through the import of water in virtual form. Sixth, global trade in water-intensive commodities offers the opportunity of global water saving if this trade is from countries with high to countries with low water productivity.

Hoekstra's rationale for the water footprint approach is well argued if not compelling (Hoekstra 2009). However, as a research agenda it is yet to take off in terms of scholarly work and policy application. As it is, the program falls short of explaining why the use of water footprints can be a viable alternative given their contractual and transaction cost implications, especially the problem of allocating those rights. It is yet to be established whether the associated transaction costs of creating the global infrastructure for such trade is actually worth the perceived benefits of adopting the approach compared to second best alternatives. The politics of water footprints is also not understood if indeed politically feasible.

\subsection{New Institutional Economics}

The second pillar of water governance research, we argue, is grounded in new institutional economics. In fact, much of the analytics of good governance has its origins from the work of new institutional economists such as North (1990) on institutions in general, Williamson (2002) on transaction cost, Coase (1960) on property rights as well as mechanism design theorists such as Maskin and Tirole (2004), among others. Here, we only review some of the theoretical core of new institutional economics such as the theory of incomplete contracts and transaction cost, agency theory, theory of property rights and the commons, and noncooperative game theory. For readers interested in the broader literature, see the Handbook of New Institutional Economics edited by Shirley and Menard (2005).

The theory of incomplete contracts has several important implications for water governance 2.0. For instance, the theory suggest that 1) inefficient outcomes in water supply can be understood as a function of incomplete contracts; 2) that contracts cannot be fully specified (i.e. obligations of both parties are not fully specified for all possible situations in the real world); and 3) if a contract can be renegotiated, it can be made more complete in the future assuming that a modicum of rule of law exists in that context to allow for credible contracting.

Similarly, the theory of transaction cost - or the cost of exchange - applied to water governance, suggests that 1) complete specification of water rights and contract enforcement is problematic; 2) opportunism by contracting parties is inherent; 3) that there is no optimal water governance structure (markets, hierarchies, franchises, cooperatives) but instead parties should settle for a remediable solution, i.e. second best solution with net benefits.

In practice, the theory of incomplete contracts and transaction cost can be used to help diagnose and possibly resolve a variety of important water governance issues. For instance, incomplete contracts and transaction costs can help explain the failure of privatization of 
water utilities (Araral 2009). Second, they can help explain why most water utilities remain controlled by governments despite their inefficiencies. Third, and more generally, Menard and Saussier (2000) have demonstrated how contractual arrangements (or modes of governance) actually matter to the performance of urban water utilities.

Fourth, the theories of incomplete contracts and transaction cost can also explain why most concession contracts for water are often renegotiated and or returned to the government. For instance, most renegotiated or failed concession contracts in Latin America did not adequately account for a variety of risks such as political, commercial, financing and construction risks and as a result led to failures in the privatization of concession contracts. Consequently, the municipalization of urban water supply is now on the rise (Foster et al. 2003; Guasch 2004).

Fifth, these theories can likewise be extended to explain the difficulties of creating a market for water trading in developing countries where water rights are unclear and contract enforcement is weak or corrupted. They can also be used to understand the practical and contractual challenges of creating virtual water markets using water footprints.

Sixth, more recently, the concept of unbundling the water value chain (i.e. unbundling wholesale, distribution and retail), the concepts of competition for the market and competition in the market as well as the idea of output based water aid are some of the recent innovative implications coming from institutional economics that are currently being pilot tested.

In conclusion, in less than a decade, new institutional economics - with its focus on water rights, regulations, transaction cost and modes of governance - has shown its potentials as an analytic and prescriptive approach to advance the second-generation research agenda on water governance.

\subsection{Political Economy}

We refer to the third approach to water governance research as the political economy approach. This approach is concerned primarily about the interaction of the politics and economics - particularly the distributional aspects of water reform which has generally remained a black hole in the literature. Many prescriptions for improving water governance such as improving water rights, marginal cost pricing and privatization of utilities, among others - are naïve about the political dimensions of the problem which explains why there are very few successful water governance reforms. Indeed, water governance, to the extent that it involves conflict in the allocation and use of an increasingly scarce and valuable resource is an inherently political subject.

Perhaps the most significant empirically and theoretically grounded study on the political economy of urban water reform is that of Shirley (2002). Based on a case study of six urban water reforms in Africa and Latin America, Shirley examined the politics, economics and micro institutional (regulatory, judicial, legal, political) determinants of successful and failed urban water supply reforms.

Clarke and Xu (2004) likewise employ a political economy analysis to explain the determinants for successful water utilities privatization based on six case studies from Africa and Latin America. He argues that water sector reform must be politically desirable which is "more likely when the public operator is performing poorly and when government supporters benefit from reform - usually through improved quality, system expansion or reduced subsidies." In addition, he argues that reform has to be politically feasible and suggest "if the government relies heavily upon groups that will lose from reform through price increases or job losses, reform will be unlikely."

Another important study is that of Dinar (2000) on the political economy of water pricing. Using theories of political economy and illustrated by case studies, Dinar emphasizes the link between property and pricing regimes, the power and influence between and within water resource management organizations, and shows the role of asymmetric information for the implementation of efficient pricing reform. 
Konca (2005) on the other hand provides an excellent treatment of the politics of transnational water governance using international relations theory. He argues that threats to the world's water commons have resisted the establishment of effective global or interstate water agreements through intergovernmental bargaining because the conditions for successful interstate cooperation - effective state authority, stable knowledge frameworks, and a territorialized understanding of nature - cannot be imposed upon water controversies. However, he argues, while interstate water diplomacy has faltered, less formalized institutions - socially and politically embedded rules, roles, and practices - have emerged to help shape water governance locally and globally. Along with Hoekstra's water footprint approach, which has focused on the externalities of transnational water governance but has generally ignored its politics, Konca's approach offers a potentially fruitful area of research for water governance 2.0.

In contrast, the theory of the commons and property rights along with the theory of collective action and non-cooperative game theory can be - and has been — used to explain a wide range of intractable problems in water resource management. These include problems of water pollution, unregulated ground water depletion as well as conflict and cooperation in river basin, watershed and irrigation.

These theories offer several policy relevant implications. First, conflicts among water users - between farmers, industries and states - are likely to arise when water is salient but scarce and where water rights are unclear and enforcement costs are prohibitive. Because the allocation of rights to a valuable and scarce resource is problematic and contested, a transparent, participatory and negotiated process of rights allocation is an efficient, equitable and sustainable solution.

Second, the theory of collective action in the commons as well as non-cooperative game theory has been the main theoretical basis for supporting or contesting the logic of integrated water resources management. The implications derived from the theory of contracts, property rights and transaction costs would support Biswas' (2004) critique of the problems of integrated water resources management (IWRM) at the same time offer a coherent diagnostic tool for why IWRM in practice is problematic.

In conclusion, political economy approaches to water governance offers implications for our understanding of the challenges of urban utilities reform, integrated water resources management, water rights and management of water conflicts, water tariffs and privatization of water utilities, among others.

\subsection{Public Administration}

The fourth pillar of water governance 2.0 is the public administration approach, which is concerned with the question why majority of water utilities and irrigation agencies in developing countries are inefficient. Its operational focus is on the organization and management determinants of the performance of water bureaucracies such as financial and personnel autonomy, human resource management practices such as compensation, leadership development, training, incentive structure, and problems generally associated with government failures.

The theoretical core of public administration problems in the water sector is rooted in a series of agency problems (Araral 2008). Agency problems arise because principals do not exactly have the same interests as their agents and because it is costly for the principals to monitor their agents. Agents have more information about their activities than their principals, which allows them to pursue their own interests to some extent. The principal then faces the task of creating organizational arrangements that minimize the sum of the costs of the undesirable behavior of agents and of the activity undertaken to control it.

While agency loss - the cost of inefficiencies and cost of remedying them - is universal in all organizations, several factors make them a more serious problem for public bureaus 
than private firms (Weimer and Vining 2005) and by implication, to public water utilities. These factors include difficulty of valuing outputs and performance and the lack of competition among public bureaus. The difficulty of valuing outputs and performance makes it difficult to determine the optimal sizes of public water bureaucracies and results into varying degrees of $\mathrm{x}$-inefficiencies and allocative inefficiencies.

In addition, lack of competition gives public water agencies weaker incentives to innovate, as - unlike private firms - they are not driven out of existence for failure to do so. This lack of competition eventually leads to varying degrees of dynamic inefficiencies. What this suggests is that the variation in the performance of water utilities is a function of the ability to solve these various types of inefficiencies.

More generally, these inefficiencies can be attributed to a myriad of government failures, in addition to market failures. The theory of government failures is not as well developed as market failures but the central idea is that government interventions can often lead to inefficient outcomes. Rogers (2002) cites the following examples of government failure in the water sector: corruption, price regulation, subsidies to resource users and polluters, inappropriate tax incentives and credits, over-regulation or under-regulation, bureaucratic obstacles or inertia, conflicting regulatory regimes, short-sightedness, voter ignorance and imperfect information.

Moreover, government failure is also closely associated with a myriad of problems: regulatory capture by special interest groups (water operators, industries, farmers lobbies, etc.), little incentives by bureaucrats for operational efficiency, imprecise reflection of consumer preferences (due to monopoly characteristics of urban water supply), inability of the government to control and regulate the sustainable use of water resource (due to fragmentation and information problems) and independence and impartiality of regulatory agencies (due to the political characteristics of water).

Only a few of this myriad of government failures have been studied for their implications to water governance. These include for example the effects of price regulation on the performance of water utilities (Araral 2008; Dinar 2000), bureaucratic obstacles, inertia or perverse incentives in water utilities (Araral 2010), irrigation agencies (Araral 2009) and the impact of regulating public utilities (Ehrhardt and Janson 2010).

Molle et al. (2009) - based on a historical overview of the evolution, motivation and challenges faced by hydraulic (mainly irrigation) bureaucracies - argue that they have become an end by itself, "a symbol of state power and a fuel for rent seeking." In the case of the Philippine irrigation bureaucracy, Araral (2009) argues that the perverse incentive problems faced by irrigation bureaucrats were compounded by perverse incentives embedded in foreign aid overtime.

Araral (2008) also studied the determinants of the performance of one of the best public water utilities in developing countries, the Phnom Penh Water Supply Authority (PPWSA) in Cambodia. Similarly, Tortajada (2006) examined the determinants of performance of one of the best urban water supply agencies in the world, Singapore's Public Utilities Board. Both papers conclude that corporate governance - autonomy of the utility, performance management and compensation, professional staff and progressive leadership, among others - are some of the key factors for their success. Ehrhardt and Janson (2010) examined the effects of regulation on the performance of public water utilities and conclude that it is not useful in isolation because of the incentives embedded in the public sector.

Studies on corruption in the water sector in the last decade are few and are mostly descriptive or assertive, for example Plummer and Cross (2007), Davis (2004), and Zinnbauer and Dobson (2008). The exceptions include Rinaudo (2002) who provided a detailed account of corruption on irrigation in Pakistan, and Venot et al. (2011) on water reservoirs in Ghana. As yet, there are no robust studies on the effects of corruption in the water sector.

In conclusion, the public administration approach to water governance-with its focus on agency problems and government failures in general - has important implications for improving 
the efficiency, effectiveness, responsiveness and sustainability of public water agencies especially in developing countries.

\section{Conclusion and Implications}

Most scholars agree that improving water governance is the key to addressing water insecurity in developing countries. We reviewed the literature on water governance and find that, first, there appears to be little consensus on the scope and definition of water governance. Second, while water governance is inherently multidisciplinary and interdisciplinary in nature, there is little evidence of this in the literature. Third, the literature is generally descriptive and argumentative and offers little theoretical coherence. The literature generally does not provide robust analysis of the incentive issues that we argue should be the core of water governance research. Finally, there is no consensus yet on how to approach the study of water governance.

Based on this review, we argued for a second-generation multidisciplinary research agenda on water governance, which integrates economics, politics and administration, pays more attention to incentive issues and has clear policy implications.

From public economics, we examined theories of market failures in particular the theory of the commons, property rights and public goods to explain the challenges of water resources management. From the new institutional economics, we argue that theories of water rights, contract, transaction cost and modes of governance can help explain the challenges of integrated river basin management, public-private partnership for water utilities, creating a market for water trading in developing countries, failure of privatization of water utilities and why most of utilities remain controlled by governments despite their inefficiencies.

Political economy approaches to water governance offers implications for our understanding of the challenges of urban utilities reform, integrated water resources management, water rights and management of water conflicts, water tariffs and privatization of water utilities, among others. The public administration approach to water governance - with its focus on government failures and the associated agency problems and incentive issues - offers an important diagnostic and prescriptive approach for improving the governance of inefficient public water agencies in developing countries.

Finally, the rich theoretical and policy implications drawn from these analytical tools - which we have illustrated in the areas of integrated water resources management, improving efficiency of water utilities, privatization of utilities and public-private partnerships, water pricing reforms, virtual waters/water trading — suggest that they can serve as an impetus for a second-generation research agenda on water governance.

Acknowledgments We are grateful to the anonymous reviewers and editors for their valuable comments and suggestions. This work is supported by the National Science Foundation of China (grant no 70973064) and the Program for New Century Excellent Talents in University (grant no NCET-11-0278).

Open Access This article is distributed under the terms of the Creative Commons Attribution License which permits any use, distribution, and reproduction in any medium, provided the original author(s) and the source are credited.

\section{References}

Abu-Sharar TM, Al-Karablieh EK, Haddadin MJ (2012) Role of virtual water in optimizing water resources management in Jordan. Water Resour Manag 26(14):3977-3993. doi:10.1007/s11269-012-0116-Z 
Ako AA, Eyong GT, Nkeng GE (2010) Water resources management and integrated water resources management (IWRM) in Cameroon. Water Resour Manag 22(9):1241-1257. doi:10.1007/s11269-009-9476-4

Araral E (2008) Public provision for urban water: getting prices and governance right. Governance 21(4):527549. doi:10.1111/j.1468-0491.2008.00412.x

Araral E (2009) The failure of water utilities privatization: synthesis of evidence, analysis and implications. Policy Soc 27(3):221-228. doi:10.1016/j.polsoc.2008.10.006

Araral E (2010) Reform of water institutions: review of evidences and international experiences. Water Policy 12(1):8-22. doi: $10.2139 /$ ssrn. 1464705

Bauer CJ (2004) Results of Chilean water markets: empirical research since 1990. Water Resour Res 40:W09S06. doi:10.1029/2003WR002838

Biswas AK (2004) Integrated water resources management: a reassessment. Water Int 29(2):248-256. doi:10.1080/ 02508060408691775

Biswas AK, Tortajada C (2010) Future water governance: problems and perspectives. Int J Water Resour Dev 26(2):129-139. doi:10.1080/07900627.2010.488853

Bjornlund H, McKay J (2002) Aspects of water markets for developing countries: experiences from Australia, Chile, and the US. Env Dev Econ 7(4):769-795. doi:10.1017/S1355770X02000463

Brewer J, Glennon R, Ker A, Libecap GD (2008) Water markets in the West: prices, trading, and contractual forms. Econ Inq 46(2):91-112. doi:10.1111/j.1465-7295.2007.00072.x

Briscoe J (2009) Water security: why it matters and what to do about it. Innovations 4(3):3-28. doi:10.1162/ itgg.2009.4.3.3

Brooks R, Harris E (2008) Efficiency gains from water markets: empirical analysis of water move in Australia. Agric Water Manag 95(4):391-399. doi:10.1016/j.agwat.2007.10.020

Brookshire DS, Colby B, Ewers M, Ganderton PT (2004) Market prices for water in the semiarid West of the United States. Water Resour Res 40:W09S04. doi:10.1029/2003WR002846

Brown TC (2006) Trends in water market activity and price in the Western United States. Water Resour Res 42, W09402. doi:10.1029/2005WR004180

Chikozho C (2008) Globalizing integrated water resources management: a complicated option in Southern Africa. Water Resour Manag 22(9):1241-1257. doi:10.1007/s11269-007-9223-7

Clarke G, Xu C (2004) Privatization, competition, and corruption: how characteristics of bribe takers and payers affect bribe payments to utilities. J Publ Econ 88:2067-2097. doi:10.1016/j.jpubeco.2003.07.002

Coase R (1960) The problem of social cost. J Law Econ 3(1):1-44

Cosgrove WJ, Rijsberman FR (2000) World water vision: making water everybody's business. Earthscan, London

Davis J (2004) Corruption in public service delivery: experience from south Asia's water and sanitation sector. World Dev 32(1):53-71. doi:10.1016/j.worlddev.2003.07.003

Dinar A (ed) (2000) The political economy of water pricing reforms. Oxford University Press, New York

Ehrhardt D, Janson N (2010) Can regulation improve the performance of government-controlled water utilities? Water Policy 12(1):23-40

Foster V, Guasch JL, Pinglo ME, Sirtaine S (2003) Has private investment in infrastructure in Latin America been profitable? An empirical analysis 1990-2000. World Bank, Washington, D.C

Global Water Partnership (2000) Towards water security: a framework for action. Stockholm, Sweden

Global Water Partnership (2002) Effective water governance. Stockholm, Sweden

Godden L, Ison RL, Wallis PJ (2011) Water governance in a climate change world: appraising systemic and adaptive effectiveness. Water Resour Manag 25(15):3971-3976. doi:10.1007/s11269-011-9902-2

Gopalakrishnan C, Tortajada C, Biswas AK (eds) (2005) Water institutions: policies, performance and prospects. Springer, Berlin

Guasch JL (2004) Granting and renegotiating infrastructure concessions: doing it right. World Bank Institute, Washington, D.C

Harris E (2011) The impact of institutional path dependence on water market efficiency in Victoria, Australia. Water Resour Manag 25(15):4069-4080. doi:10.1007/s11269-011-9884-0

Hirsch P (2006) Water governance reform and catchment management in the Mekong region. J Environ Dev 15(2):184-201. doi:10.1177/1070496506288221

Hoekstra AY (2009) Water security of nations: how international trade affects national water scarcity and dependency. In: Jones $\mathrm{J}$ et al (eds) Threats to global water security. Springer, Berlin, pp 2736

Hoekstra AY, Chapagain AK (2007) Water footprints of nations: water use by people as a function of their consumption pattern. Water Resour Manag 21(1):35-48. doi:10.1007/s11269-006-9039-x

Kashyap A (2004) Water governance: learning by developing adaptive capacity to incorporate climate variability and change. Water Sci Technol 49(7):141-146

Konca K (2005) Governing water: contentious transnational politics and global institution building. MIT Press, Boston

Maskin E, Tirole J (2004) The politician and the judge: accountability in government. Am Econ Rev 94(4):1034-1054. doi:10.1257/0002828042002606 
Menard C (2008) Redesigning public utilities: the key role of micro-institutions. In: Kornai J, Mathyas L, Roland G (eds) Corruption, development and institutional design. Palgrave- MacMillan, London, pp 189-202

Menard C, Saussier S (2000) Contractual choices and performances: the case of water distribution in France. J Ind Econ 92:385-404

Molle F, Mollinga PP, Wester P (2009) Hydraulic bureaucracies and the hydraulic mission. Water Altern 2(3):328-349

Mollinga PP (2008) Water, politics and development: framing a political sociology of water resource management. Water Altern 1(1):7-23

North D (1990) Institutions, institutional change and economic performance. Cambridge University Press, New York

OECD (2011) Water governance in OECD countries: a multi-level approach. OECD Publishing, French. OECD iLibrary Web. http://www.oecd-ilibrary.org/environment/water-governance-in-oecd-countries_9789264119284-en

Pahl-Wostl C, Gupta J, Petry D (2008) Governance and the global water system: a theoretical exploration. Glob Gov 14(4):419-435

Plummer J, Cross P (2007) Tackling corruption in the water and sanitation sector in Africa: starting the dialogue. In: Campos E, Pradhan S (eds) The many faces of corruption. World Bank, Washington, D.C

Rinaudo J (2002) Corruption and allocation of water: the case of public irrigation in Pakistan. Water Policy 4(5):405-422. doi:10.1016/S1366-7017(02)00037-5

Rogers P (2002) Water governance in Latin America and the Caribbean. Inter-American Development Bank, Washington, D.C

Rogers P, Hall AW (2003) Effective water governance. TEC Report No. 7, Global Water Partnership, Stockholm

Saleth RM, Dinar A (2005) The institutional economics of water: a cross-country analysis of institutions and performance. Northampton, MA

Shirley M (ed) (2002) Thirsting for efficiency: the economics and politics of urban water system reform. Elsevier Science, Oxford

Shirley M, Menard C (eds) (2005) Handbook of new institutional economics. Edward Elgar, London

Stein C, Ernstson H, Barron J (2011) A social network approach to analyzing water governance: the case of the Mkindo catchment, Tanzania. Paper presented at Proceedings of the XIVth World Water Congress, 25-29 September. Porto de Galinhas, Pernambuco

Timmerman JG, Pahl-Wostl C, Möltgen J (2008) The adaptiveness of IWRM: analyzing European IWRM research. IWA Publishing, London

Tortajada C (2006) Water management in Singapore. Int J Water Resour Dev 22(2):227-240. doi:10.1080/ 07900620600691944

Tropp H (2007) Water governance: trends and needs for new capacity development. Water Policy 9(2):19-30. doi:10.2166/wp.2007.137

UNDP Water Governance Facility (2013) What is water governance? UNDP WGF Web. http://www.watergovernance.org/ whatiswatergovernance

Venot JP, Andreini M, Pinkstaff CB (2011) Planning and corrupting water resources development: the case of small reservoirs in Ghana. Water Altern 4(3):399-423

Wang Y (2012) A simulation of water rights market with transaction costs. Agric Water Manag 103:54-61. doi:10.1016/j.agwat.2011.10.017

Wang Y, Ching L (2013) Institutional legitimacy: an exegesis of normative incentives. Int J Water Resour Dev. doi:10.1080/07900627.2013.787831

Wang HR, Dong YY, Wang Y, Liu Q (2008) Water right institution and strategies of the Yellow River Valley. Water Resour Manag 22(10):1499-1519. doi:10.1007/s11269-008-9239-7

Weimer D, Vining A (2005) Policy analysis: concepts and practice, 4th edn. Prentice Hall, New Jersey

Wiek A, Larson KL (2012) Water, people, and sustainability - a systems framework for analyzing and assessing water governance regimes. Water Resour Manag 26(11):3153-3171. doi:10.1007/s11269-012-0065-6

Wilchens D (2010) Virtual water: a helpful perspective, but not a sufficient policy criterion. Water Resour Manag 24(10):2203-2219. doi:10.1007/s11269-009-9547-6

Williamson OE (2002) The theory of the firm as governance structure: from choice to contract. J Econ Perspect 16(3):171-195

Yang H, Zehnder A (2007) Virtual water: an unfolding concept in integrated water resources management. Water Resour Res 43, W12301. doi:10.1029/2007WR006048

Zinnbauer D, Dobson R (eds) (2008) Global corruption report 2008: corruption in the water sector. Cambridge University Press, Cambridge 